ENTREPRENEURSHIP AND SUSTAINABILITY ISSUES

ISSN 2345-0282 (online) http://jssidoi.org/jesi/

2019 Volume 6 Number 4 (June)

http://doi.org/10.9770/jesi.2019.6.4(66)



Publisher

http://jssidoi.org/esc/home

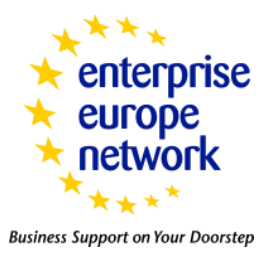

CASPA

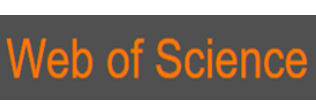

1) Clarivate

\title{
STAFFING SEARCH AND RECRUITMENT OF PERSONNEL ON THE BASIS OF ARTIFICIAL INTELLIGIENCE TECHNOLOGIES
}

\author{
Alena Borisova ${ }^{1}$, Madina Rakhimberdinova ${ }^{2}$, Elvira Madiyarova ${ }^{3}$, Inna Riazantseva ${ }^{4}$, \\ Natalia Mikidenko ${ }^{5}$ \\ ${ }^{1}$ Novosibirsk State Technical University, 20 Prospekt K. Marksa, Novosibirsk, Russia \\ 2,3,4 D. Serikbayev East Kazakhstan State Technical University, 69 Protozanov Street,Ust-Kamenogorsk, Kazakhstan \\ ${ }^{5}$ Siberian State University of Telecommunications and Informatics, 86 Kirova Street, Novosibirsk, Russia \\ E-mails: ${ }^{1} \underline{\text { bborisova2012@yandex.ru }} ; \frac{{ }^{2} \text { rmu_uk@mail.ru }}{{ }^{5} \text { nl_nsk@mail.ru }}{ }^{3}$ emadiyarova@mail.ru $;{ }^{4}$ zentr_riv@mail.ru $;$
}

Received 18 October 2019; accepted 19 January 2020; published 30 March 2020

\begin{abstract}
The key reasons for the transformation of the domestic labor market and the grounds for changing approaches to the formation of staffing are identified. The development of technological solutions to automate the functions of attracting applicants and the primary diagnosis of their suitability to the requirements of the position and organization are presented. A comparative analysis of the possibilities provided by technological solutions for automated search and attracting candidates is given. The problem of search specialization and interaction with the target audience is highlighted. The description of the technological solution for work with the expanded market offer on the basis of point response to information on the offer of a new working place is offered. The article describes the content of the technology and presents a new algorithm for the domestic market search and work with the target audience. Intelligent search and evaluation of the suitability of the applicant in the new technological solution is based on the information trail left by the person in the network.
\end{abstract}

Keywords: staffing; search and recruitment tools; technology; labor market analysis; closing a vacancy

Reference to this paper should be made as follows: Borisova, A., Rakhimberdinova, M., Madiyarova, E., Riazantseva, I., Mikidenko, N. 2020. Staffing search and recruitment of personnel on the basis of artificial intelligence technologies. Entrepreneurship and Sustainability Issues, 7(3), 2456-2469. http://doi.org/10.9770/jesi.2020.7.3(66)

JEL Classifications: M12, M20.

\footnotetext{
* This research was supported by the project, which has received funding from the Ministry of Education and Science of the Russian Federation, project 26.2024.2017/PCH. The results of the research were obtained within the framework of the state task of the project.
} 


\section{ENTREPRENEURSHIP AND SUSTAINABILITY ISSUES}

ISSN 2345-0282 (online) http://jssidoi.org/jesi/

2019 Volume 6 Number 4 (June)

http://doi.org/10.9770/jesi.2019.6.4(66)

\section{Introduction}

Domestic practice of stuffing formation is passing a stage of active development. Strategies and concepts of organizations to identify the need for personnel are being transformed, approaches to position an employer's HR brand are being changed, and traditional ways of attracting and selecting applicants are being improved. The need to test new channels and methods, as well as digitalization of diagnostic tools of the applicant's professional suitability is due to significant reasons (Boikova and Lapshina 2018).

Firstly, rapid changes in business conditions and the need to adapt to them happen almost non-stopping (Borisova 2016; Chehabeddine, Tvaronavičienè, 2020; Lincényi, Čársky, 2020). As a result, the priority for companies often appears to be tools for point response to emerging problems embedded in the management system.

Secondly, the business focuses on the return of investments on resources. The return of investments in the formation of personnel depends on the degree of impact on the target audience, the differentiation of which involves the use of a diverse arsenal of means of communication. Therefore, the means of formation also need differentiation and justification of the impact/payback for different target groups (Butsyk and Demenenko 2018).

Thirdly, the increased selectivity of staff in choosing an employer and, as a result, the struggle of employers for the right employees, especially in the labor market has place. Employment strategies implemented on the market today are more flexible and mobile (Danshina and Vasilenko 2016). The change of generational groups also increases the significance of this cause. Employees of generation $\mathrm{Z}$ are extremely selective in the choice of work and organization, as a result, the competition for employees between employers increases (Demenenko and Sarkisyan 2017).

The identified reasons indicate the demand for the market to improve traditional tools of staffing. Criteria for improvement include the following: the speed of closing a vacancy, the breadth of the target audience, the cost of recruitment and selection, the reliability of data; the predictive value of the hiring decision and the retention of new employees in the organization.

It seems relevant to conduct:

- a review of existing and developing technological solutions to improve traditional staffing tools;

- an assessment of technological solutions to meet the above criteria and the definition of niches for innovation;

- an analysis of successful / not successful practices in the use of new technologies;

- an assessment of development prospects and ways to prevent / overcome threats to the functional area of

"recruitment", implemented by traditional instrumental solutions in the HR departments of companies.

The intent and the logic of this article research are defined by these objectives (Glupenykaya 2014).

\section{Research background}

The staffing issues of the company are at the junction of many disciplines: Human Resource Management, Labor Economics, Personality Psychology, and General Management. The list of interdisciplinary interaction has recently included information areas, i.e. artificial intelligence technologies, tools for processing big data and process modeling, tools for building artificial neural networks and predictive analytics. The basis of traditional approaches to the formation of the company's staffing is to diagnose to what extent a candidate's professionalism and personal qualities are in the compliance to the requirements of the position of the company on the basis of a direct appeal to the participants of interaction - the applicant or employer. The response to a vacancy or a request for a resume, announced on the job site, is the starting stages of launching the staffing process (Andonova, Nikolova, Dimitrov 2019). 


\section{ENTREPRENEURSHIP AND SUSTAINABILITY ISSUES}

ISSN 2345-0282 (online) http://jssidoi.org/jesi/

2019 Volume 6 Number 4 (June)

http://doi.org/10.9770/jesi.2019.6.4(66)

Information technology greatly enriches the tools for diagnosing the suitability of the applicant and the selection of employees. So, video resumes, interviews via Skype, the initial selection and communication via instant messengers and chat-bots have become habitual and traditional.

The empirical data confirming high efficiency of using new information tools in processes are accumulated: attracting applicants through social networks; positioning the employer in the labor market and improving the employer's HR brand; relocation of talents and formation of personnel reserve; selection of employment channels and the effectiveness of this choice for applicants and organizations; the diagnostic suitability of a specific job, including the job interview and building a profile about the suitability of the means of neurophysiology; generation and growth of conversion funnel selection of applicants (Cassela and Hanaki 2016).

The use of such tools can reduce the resource support for the selection of personnel and expand the territorial localization of participants, increase awareness of the company in the labor market, and contributes to the targeted search for an employer or a specialist (Mansurov 2018).

However, in the referred works the main emphasis is placed on enriching the traditional approach to the formation of staffing organization tools that replace manual labor of a HR-Manager. This article focuses on the presentation of new information tools that expand the traditional vision of the company's s staffing: the search in the mode of direct response of interaction participants to employment requests is replaced by technologies that allow forming demand and supply of labor in the online mode without announcing the need for interaction. Thus, the use of the following technologies allows you to expand the volume of supply of the labour market and to significantly reduce the asymmetry of information interaction of the participants - the employer and the applicant.

In our opinion, it is significant that new information technologies expand the traditional approach to staffing, as it becomes possible to find a candidate and an employer without a direct request for the need: at work or a new employee. And the results of using such technologies allow us to speak not only and not so much about saving resources, but also about the quality growth of the formation of the company personnel.

\section{Market review of technological solutions for searching and selecting target applicants for the organization}

The speed of processes automation of and functional depends on:

- the interest of developers, service user- companies and, finally, startup innovators ready to invest in development;

- readiness of the environment and people to perceive technological solutions and evaluate the benefits of their use;

- the scale of financial investments in development.

Studies show that the domestic market is significantly behind the speed of development and implementation of the global pace (Ananeva 2016). There is significant growth potential over the coming years. The market with high attractiveness for investors and developers has been differentiated. The specialization of companies in automated functional areas of HR-management is defined according to the breadth of management tasks.

Automation of selection, despite the already long history of formation, is being significantly modernized in the present : the shift of focus from traditional tools built into a single management system to local solutions that allow to solve deeper the narrow problem of finding, attracting personnel and diagnosing their professional suitability is fixed. Analysis of key developers of automated technologies for search, attraction and primary diagnostics of applicants (Table I) found that almost all platforms implement a similar scheme of generating the input flow of applicants - through the collection of resumes from job sites and social networks. Accordingly, all solutions apply to almost the same initial database of applicants. This leads to greater competition in the demand 


\section{ENTREPRENEURSHIP AND SUSTAINABILITY ISSUES}

ISSN 2345-0282 (online) http://jssidoi.org/jesi/

2019 Volume 6 Number 4 (June)

http://doi.org/10.9770/jesi.2019.6.4(66)

market, and as a result, makes the position of applicants more advantageous for a set of requirements for the employer (Khoreva, Vaiman and Kostane 2018).

Restrictions on the candidates search reduce the possible closure for the job vacancies with unique requirements and those with a limited range. Therefore, the introduction of technological solutions to bypass these restrictions, in our opinion, can be a key advantage of companies operating in the recruitment market. Solutions should provide an opportunity to expand the target audience and channels of its involvement.

The target audience, we believe, are not only applicants in the open status of "looking for a job", but also candidates who have a current job with the intention of considering a proposal to change it. Today, the market has solutions that allow to identify candidates, assess the strength of their intentions and precisely convey to them information about the job (for example, Hr-robot HRom (Table 1).

Technological solutions presented on the market differ in parameters: the volume of investments involved in the development and promotion, the cost of services for users, organization of work and interaction with the customer, implemented functional and the ability to integrate into information systems.

For example, Skillaz platform http://skillaz.co/ received investment support from market leaders (Sberbank, Gazpromneft, MegaFon) for the development of the required pre-agreed functional. Skillaz also offers its product on the open market at a very "corporate" cost. The product is based on the SAP platform, which allows to fully or partially automating the selection and attraction of applicants. Sources of data on applicants are almost all Russian work sites of the Russian Federation and popular social networks (Vkontakte, Facebook).

The list of functionalities of the system also includes: the purpose of the VR interviews, calling applicants with forces of robotic services, SMS alerts for candidates. Platform developers declare the compatibility of their solution with e-staff and success factors, which is convenient for customers who use these solutions. At the same time, Skillaz offers its customers the purchase of a license for the SOFTWARE, and its support.

Since January 2019, Sberbank has completely switched to Skillaz solutions, which can be regarded, including as the fulfillment of the requirements of the resolution, by which the Russian Government has made changes to the requirements for programs, information about which is included in the register of Russian software.

Table 1. Technological solutions of the personnel search and selection market

\begin{tabular}{|c|c|c|c|}
\hline \multirow[t]{2}{*}{ Name } & \multicolumn{2}{|c|}{ Implementation } & \multirow{2}{*}{$\begin{array}{l}\text { cost policy and integration } \\
\text { opportunities }\end{array}$} \\
\hline & search and attraction & diagnostics of applicants & \\
\hline $\begin{array}{l}\text { Skillaz } \\
\text { (http://skillaz.co/) }\end{array}$ & $\begin{array}{l}\text { collecting resumes from job } \\
\text { sites and social networks }\end{array}$ & $\begin{array}{l}\text { according to the specified } \\
\text { criteria using automated } \\
\text { surveys and tests. } \\
\text { The system allows you to } \\
\text { double-evaluate the } \\
\text { effectiveness of employees } \\
\text { hired with Skillaz-after } 6 \text { and } \\
12 \text { months from the start of } \\
\text { their work in the company }\end{array}$ & $\begin{array}{l}\text { customers are invited to buy a } \\
\text { license for the software, with } \\
\text { support. Starting price is from } \\
5 \text { million e-staff and success } \\
\text { factors }\end{array}$ \\
\hline Potok (https://potok.io/ ) & $\begin{array}{l}\text { collecting resumes from job } \\
\text { sites and social networks }\end{array}$ & $\begin{array}{l}\text { diagnosis of applicants is not } \\
\text { carried out. The selection } \\
\text { funnel is being evaluated }\end{array}$ & $\begin{array}{l}\text { integration with } 1 \mathrm{C}, \mathrm{SAP} \text { and } \\
\text { Webtutor. }\end{array}$ \\
\hline
\end{tabular}




\begin{tabular}{|c|c|c|c|}
\hline North (https://sever.ai/) & $\begin{array}{l}\text { collecting resumes from job } \\
\text { sites and social networks }\end{array}$ & $\begin{array}{l}\text { facial expressions and moods } \\
\text { of the candidate are } \\
\text { recognized during the video } \\
\text { interview. The creators claim } \\
\text { that the system understands } \\
\text { how critical a particular skill } \\
\text { for a particular job is. }\end{array}$ & $\begin{array}{l}\text { There are no boxed solutions, } \\
\text { the company plans to hire no } \\
\text { more than } 20 \text { customers per } \\
\text { year. The cost is calculated for } \\
\text { the project }\end{array}$ \\
\hline $\begin{array}{l}\text { Friendwork } \\
\text { (http://friend.work/) }\end{array}$ & $\begin{array}{l}\text { collecting resumes from job } \\
\text { sites and social networks }\end{array}$ & $\begin{array}{l}\text { diagnosis of applicants is not } \\
\text { carried out. The selection } \\
\text { funnel is being evaluated }\end{array}$ & $\begin{array}{l}\text { the estimated price is } \\
\text { determined in the context of } \\
\text { one workplace recruiter - from } \\
1725 \text { rubles/month. } \\
\text { Integration with } 1 \mathrm{~S}\end{array}$ \\
\hline $\begin{array}{l}\text { Robot Vera } \\
\text { (https://robotvera.com) }\end{array}$ & $\begin{array}{l}\text { collecting resumes from job } \\
\text { sites and social networks }\end{array}$ & $\begin{array}{l}\text { automated surveys and tests } \\
\text { are conducted }\end{array}$ & $\begin{array}{l}\text { the estimated price depends on } \\
\text { the number of successful } \\
\text { responses to the call } \\
\text { (minimum package is } 62500 \\
\text { rubles for } 250 \text { responses) }\end{array}$ \\
\hline $\begin{array}{l}\text { Handflow } \\
\text { (https://huntflow.ru/) }\end{array}$ & $\begin{array}{l}\text { collecting resumes from job } \\
\text { sites and social networks }\end{array}$ & $\begin{array}{l}\text { the system has a number of } \\
\text { analytical reports on } \\
\text { vacancies, recruiters and } \\
\text { sources of getting a resume in } \\
\text { CRM. Suitability of applicants } \\
\text { is not evaluated }\end{array}$ & $\begin{array}{l}\text { the cost is determined by a set } \\
\text { of selected services (minimum } \\
\text { package is from } 34800 \text { rubles } \\
\text { per year) }\end{array}$ \\
\hline $\begin{array}{l}\text { Hr robot HRom } \\
\text { (https://hr0m.com) }\end{array}$ & $\begin{array}{l}\text { data collection based on job } \\
\text { seeker actions as well as } \\
\text { online activity without direct } \\
\text { job search }\end{array}$ & $\begin{array}{l}\text { evaluation of applicants takes } \\
\text { place before the candidate is } \\
\text { offered a vacancy. Only } \\
\text { suitable candidates according } \\
\text { to customer requirements are } \\
\text { collected. }\end{array}$ & $\begin{array}{l}\text { the cost is calculated after free } \\
\text { market analysis, depending on } \\
\text { market conditions. Integration } \\
\text { with AMOcrm, Bitrix } 24\end{array}$ \\
\hline
\end{tabular}

Source: compiled by authors

Another popular solution for search and selection automation is https://potok.io/. The uniqueness of the solution lies in the ability to view the resume and collect contacts of target groups, add the profile of the candidate links to his pages in social networks (Facebook, Linkedin, Vkontakte, Telegram), as well as the publication of responses to the vacancy. Such features extend the functional of the solution. The system is integrated with 1C, SAP and Webtutor, which makes Potok acceptable for many domestic companies. Investment support for this decision in July 2017 allowed the company to move out of the startup category.

Technological solution - www.JungleJobs.ru - is positioned as a service for hiring employees, working on the model of the marketplace. This is an analogue of the popular online exchanges, where employers can post jobs, and recruiters and recruitment agencies can take these orders to work. The cost of selection services is also open information, and is charged immediately on the site. For example, the cost of hiring one employee with a salary of 30,000 rubles and a guarantee of two months for the employer is 57,600 rubles. At the same time JungleJobs guarantees unbiased mediation and the role of a mediator in solving complex issues. By its functions, the solution is largely the same as the site headhunter.ru, however, there are differences in the functional and method of charging intermediary services (Table 1 ).

There are solutions that can assess the relevance of resumes for specific vacancies. For Example, Sever.ai is a platform for automating the search and recruitment of employees. The functional of the solution includes communication with applicants through a robotic call center, and evaluation of video interviews. Such capabilities of the system indicate that the system core is a complex algorithm based on artificial intelligence. At the same time, the functional already involves manual work with settings, and Analytics of the platform itself. However, the system is able to study only open sources to understand the essence of the work of professions. For example, it 


\section{ENTREPRENEURSHIP AND SUSTAINABILITY ISSUES}

ISSN 2345-0282 (online) http://jssidoi.org/jesi/

2019 Volume 6 Number 4 (June)

http://doi.org/10.9770/jesi.2019.6.4(66)

can determine how many months cashiers usually work in the Bank - it is enough to analyze publicly available resumes, in the experience of which there is a "cashier in the Bank". Handy feature is, for example, for understanding the relationship between supply and demand on the labor market.

In the market some solutions are implemented that follow the path of automation of a HR specialist's full functional (recruitment, personnel audit, assessment), for example, www.hr-sreda.ru . The platform works according to the classical model: customer service creates a project (in fact the terms of reference) - Sreda aggregates offers and recruiters registered on the platform can offer their services for a specific project. Pricing is also quite transparent. The Commission fee of the platform is $30 \%$ of the order. There is a possibility for choosing a contractor (Galazzi and Lang 1998).

One of the most famous projects of the domestic market is https://robotvera.com. The project works as an automated system. The customer independently uploads the requirements for vacancies on the project website. These data are checked by the project manager, and they are automatically collected in a common database of all suitable resumes from work sites (HeadHunter, SuperJob, Zarplata.ru, Rabota66.ru and others). Then the system with the use of a robotic calling system reveals the interest of job seekers to job changes, clarifies some of the data for summary. If the candidate agrees, and is ready to continue the dialogue, this candidate is considered to be found and he/she remains in the system for the customer. We also offer the option of video interviews with candidates. The company has changed pricing for customers several times, ranging from free trial periods to the purchase of a package of "positive" candidates. In addition, the rates of "Robot Faith" affect the cost of access to resume sites, which also changes (Yershova and Sergeeva 2017).

Another popular resource with a wide range of opportunities to attract and select candidates for companies is https://friend ahhh!work/. The solution is positioned as a convenient storage of a single database of candidates collected from different sources with flexible search for it in any parameters. It supports integration with mail and calendars, and saving all actions on the candidate in the event feed. In addition to storing resumes, the system allows you to receive Analytics on the incoming number of resumes, funnels and other parameters that are subject to digitization (Izbasarov 2013). The system is popular among HR agencies, as it allows you to work with a large number of candidates and the customer in the "one window" mode.

The market has a solution to extend the functionality of the above solutions. That is https://huntflow.ru/. This solution provides the option to recognize summaries from different formats (pdf, doc. and $\mathrm{rff}$ ) and correspondence with candidates. This is useful when resumes of candidates are stored in different formats on different resources.

All of these technological solutions from the position of the employer are based on the idea of automating the process of search, attraction and primary selection of applicants. It becomes possible to reduce the labor costs of HR-specialists and the time of the open vacancy, to expand the opportunities of attracting the target audience and to increase the prognostic value of management decisions about the suitability of applicants for the requirements of the vacancy. At the same time, these decisions do not make job search easier for job seekers: they still need to write and post resumes on job sites, maintain pages on social networks, pass face-to-face or video interviews. Therefore, solutions require changing the way you search and interact with your target audience. Such solutions begin to appear on the market (for example, in the form of hr-robot HRom technology.

\section{Technology of search and interaction with the target audience}

The idea of technology to expand opportunities to find the target audience is to appeal to candidates in different statuses: both those who are in search and those who have jobs in the present. The implementation of the decisions was made by the company HRom Group and in the aggregate was represented with several sequenced steps:

- coordination of the order with the employer: employee requirements, search;

- labor market analysis; 


\section{ENTREPRENEURSHIP AND SUSTAINABILITY ISSUES}

ISSN 2345-0282 (online) http://jssidoi.org/jesi/

2019 Volume 6 Number 4 (June)

http://doi.org/10.9770/jesi.2019.6.4(66)

- clarification of order requirements;

- setting of the system parameters to close the job vacancy and formation of a long list of possible places for applicants digital locations;

- candidates screening through contact offers. Organization of the applicants flow to the customer.

Approval of the order with the employer: requirements for the employee and their search. Key parameters of the order require a coordinated presentation and agreement between the participants of the interaction: the employer and the manager of the companyHRom Group. It reveals not only a set of requirements, but also the real importance of their availability in the implementation of the functional of employees. Practice records that the initial set of the employer's requirements is overestimated and, often, is formed on the basis of internal (limited) ideas about the possibility of finding candidates in the labor market. The discrepancy in the employer's request, even in a positive finding and closing jobs, is the reason for the early departure of the employee due to the fact that they are not in accordance with the original views/ queries that are advertised in the job, don not get a proper implementation at work (Nikishina 2016). The result of this stage is the order for the search of employees for vacancies with the criteria of suitability of the applicant to the requirements of the position / function and organization.

Labor market analysis. HRom Group estimates capacity and market conditions for all customers based on key order criteria. Search criteria for suitable candidates are entered into the search system. The criteria are projected into the possible office locations of the applicant on the Internet. Information trail left by any person in the network, performing actions on the explicit or implicit job search, in the context of the criteria for the formation of the General population of applicants, allows assessing the market capacity and the ability to meet the request of the employer. Hr-robot HRom system generates information through market monitoring and allows you in retrospect (with different time steps) to name the conditions of the order: how many potential candidates matching the search criteria are available on the market; accumulated experience of closing such orders and interacting with applicants suitable to the requirements of the customer.

The ability to enter a different range of search criteria allows you to "play" and calculate the possibility of closing the job and the cost of the search. This is a significant difference between hr-robot HRom technologies from those available on the market today. As a rule, technology begins to search for applicants based on the actual limitations of the market. Technology hrHRom robot allows you to pre-format before entering the market and the investment of significant resources to work through various scenarios of closing vacancies on the basis of the possibility of "tuning" the range of customer requirements.

The specification of requirements for ordering. The information obtained at the previous stage is the basis for adjustment and approval of the requirements for the order with the employer. Various scenarios of formation for the input flow of applicants enable the employer:

a) to get an idea about the possibility of the market to close the vacancy on the requirements for applicants in the desired time;

b)to evaluate the conditions of order fulfillment in the implementation of different parameters (for example, 100 cashiers within a week, meeting 5 key criteria or 150 for the same period, if the number of key criteria is reduced to 4 );

b)to adjust, if necessary, the parameters of the order.

Interaction with the customer in the described sequence of actions causes a greater probability of positive execution of the agreement (because the order is taken by the contractor is not blind, but based on the analysis of the reality of its implementation), and also allows you to more accurately calculate the required resource support.

The configuration of the system by closing job vacancies and the formation of a long list of possible locations of the digital locations of applicants. Generation of candidates is carried out according to the criteria agreed with the employer. Hr-robot HRom technology allows to obtain information about possible locations of potentially suitable candidates (corresponding to the criteria) on the information trail. In fact, the manager receives information with a description of the places of presence in the network and the time frequency of stay on each resource of people with specified criteria (Ozernikova 2018). 


\section{ENTREPRENEURSHIP AND SUSTAINABILITY ISSUES}

ISSN 2345-0282 (online) http://jssidoi.org/jesi/

2019 Volume 6 Number 4 (June)

http://doi.org/10.9770/jesi.2019.6.4(66)

A significant difference of this search is the lack of rigid binding to the status of the candidate «in search of work". The technology carries out search in all places where the person leaves an information trace. Advanced search allows a remarkable expansion of the input stream candidates. That is a significant advantage in the implementation of the search in the labor market and the recruitment of specialists.

Candidates screening through contact offers. Organization of the flow of applicants to the customer. The list of digital locations of potentially suitable candidates serves as a basis for configuring the parameters of information distribution to the target audience and choosing ways to establish contact with the applicant. The tool kit includes a variety of tools: targeted contextual advertising, pop-up banners, targeted displays in social networks, etc. The rationale for the choice of means depends on the location of potential candidates and the degree of their preference in using different means of communication and receiving a job offer.

The negative response of the potential candidate serves as a signal for the hr-robot HRom technology and when accumulating significantly large data on the failure rate, a decision is made about the inexpediency of its use in the implementation of the order with the specified search criteria (Tolymbekova, Sultanov and Taylak 2016). A positive response of a potential candidate starts a dialogue between the candidate-operator of the call-center with clarification of the degree of interest in the vacancy and personalization of the contact. A quick (within 2 minutes) contact of the call-center employee is made with the interested applicant and arrangements for a meeting with the employer are indicated. HrHRom robot technology has a recessed configuration by the coordination of the employer's schedule of meetings with the applicant. The end of the work on the generation of the input stream of applicants is to record the fact of his arrival in the company. Technological solution Hr0m.com significantly expands the capacity of the labor market for specific needs of the employer (Uakhitzhanova, Shokhan and Omarova 2017).

Testing and launching the presented solution is carried out during the last year. Cases for different typical situations and the employer's requests have been implemented. For example, it is the order of a supermarket chain in the Siberian Federal district to search for line staff (200 employees). The order was implemented in the labor market for 81 days; a coefficient of consolidation of employees is $67 \%$.

The implementation of the cases proposed by the technological soluteion allows bypassing the previously identified limitations of the services used. The key result for applying Hr-robot HRom technology is work with the expanded market of the offer and interaction with the target audience in the compressed time parameters with high conversion of qualifying stages (Aimagambetov, Stefanov and Kuttybaeva 2016).

Application functionality.Obviously, academic and financial autonomy covers those areas in which Kazakhstan faces the greatest challenges. The rationale for providing greater autonomy to educational institutions is to improve the response of higher education institutions to the needs of the country and society. This should lead to more innovative capacity and efficiency. By continuing its transition from control to management strategy, the state can also stimulate the development of a productivity culture.

The goals of Kazakhstan regarding the education system are clearly reflected in a number of political statements that link education with the broader goal of becoming one of the leading nations in the world. Three of these statements have a direct impact on the provision of high-quality higher education by Kazakhstan:

- Strategy - 2050, which highlights the crucially important role of higher education in the process of training skilled labour;

- The State Program for the Development of Education (GPRO) for 2011-2020 (2010) and the State Program for the Development of Education and Science for 2016-2019. (2016) MES RK, which emphasize (among many other statements) the need to prepare students and undergraduates to meet the needs of industrial-innovative development, the importance of independent assessment of the qualifications of graduates and the importance of integration into the European higher education area; 
- Plan of the nation: 100 concrete steps. The main points of this document are the creation of a group of ten leading institutions of higher education, which will receive additional resources and autonomy in order to transfer their experience to other institutions of higher education, gradually eliminate centralized education management and introduce English as a widely used language of instruction.

The decline in the number of universities is mainly due to the closure of private institutions. We will determine how the number of graduates of secondary schools and the number of colleges influence the number of universities in Kazakhstan. To do this, we construct a two-factor regression model. The necessary data has presented in the following Table 2 .

Table 2. Data on the number of graduates of secondary schools and the number of colleges in Kazakhstan

\begin{tabular}{|c|c|c|c|}
\hline Year & Number of universities, units & $\begin{array}{c}\text { Graduation of 11 grades from } \\
\text { secondary schools, in thousand } \\
\text { people }\end{array}$ & Number of colleges, units \\
\hline 2006 & 176 & 199 & 482 \\
\hline 2007 & 167 & 152 & 460 \\
\hline 2008 & 143 & 143 & 470 \\
\hline 2009 & 148 & 151 & 494 \\
\hline 2010 & 149 & 173 & 494 \\
\hline 2011 & 146 & 169 & 610 \\
\hline 2012 & 139 & 149 & 785 \\
\hline 2013 & 131 & 133 & 775 \\
\hline 2014 & 126 & 129 & 780 \\
\hline 2015 & 125 & 127 & 803 \\
\hline 2016 & 130 & 138 & 808 \\
\hline 2017 & 127 & & \\
\hline
\end{tabular}

Source: compiled by authors

We introduce the following notation:

$y$ - number of universities (units);

$x_{1}$ - graduation of 11 grades from secondary schools, in thousand people

$x_{2}$ - number of colleges, units

The desired two-factor regression model will be:

$$
y=a+b_{1} x_{1}+b_{2} x_{2}
$$

We will estimate the parameters of the two-factor regression equation using the Regression analysis tool (Data Analysis in Excel). As a result of data approximation, we obtain the regression analysis protocol, which is presented below.

\begin{tabular}{lr}
\hline \multicolumn{2}{c}{ Regression Statistics } \\
\hline Multiple R & 0,929108039 \\
R-square & 0,863241749 \\
Normal R-square & 0,832851026 \\
Standard error & 6,681235382 \\
Observations & 12 \\
\hline
\end{tabular}




\begin{tabular}{|c|c|c|c|c|}
\hline & $d f$ & $S S$ & $M S$ & $F$ \\
\hline Regression & 2 & 2535,916511 & 1267,958255 & 28,404779 \\
\hline Remainder & 9 & 401,7501561 & 44,63890623 & \\
\hline Total & 11 & 2937,6666667 & & \\
\hline & Coefficients & Standard Error & t-Statistics & $P$-Value \\
\hline Y-intersection & 116,9132981 & 29,70710797 & 3,935532811 & 0,0034291 \\
\hline $\mathrm{x} 1$ & 0,367180651 & 0,131124904 & 2,800235808 & 0,0207047 \\
\hline $\mathrm{x} 2$ & $-0,050588823$ & 0,018658081 & $-2,711362622$ & 0,023944 \\
\hline
\end{tabular}

As a result, we obtain the following equation of multiple linear regression:

$$
y=116,913+0,367 x_{1}-0,051 x_{2}
$$

The coefficient of multiple correlation is $\mathrm{R}=0,93$, which indicates a close relationship between the resultant trait and two factor signs at the same time.

The coefficient of determination is $\mathrm{R}^{2}=0,86$, those $86 \%$ of the variation of the dependent variable is due to the regression obtained. Check the statistical significance and reliability of the obtained regression equation and its coefficients. From the data of the protocol for performing the regression analysis, we find that the observed value of the Fisher criterion is $F_{\text {набл. }}=28,40$. Critical Fisher criterion values at significance level $\alpha=0,05$ and the number of degrees of freedom $k_{1}=m=2, \quad k_{2}=n-m-1=9$ (where $\mathrm{n}$ is the number of observations, $\mathrm{m}$ is the number of factors) is equal to $F_{\text {крит. }}(0,05 ; 2 ; 9)=4,26$. As $F_{\text {набл. }}>F_{\text {крит. }}(28,40>4,26)$, then we can conclude about the statistical significance and reliability of the resulting regression equation.

The statistical significance of the individual coefficients of the equation will be determined using the Student's tstatistics. The observed values of this statistic for individual coefficients are respectively equal to:

$$
t_{a}=3,93, \quad t_{b_{1}}=2,80, \quad\left|t_{b_{2}}\right|=2,71 \text {. }
$$

The critical value of student's criterion at the level of significance $\alpha=0,05$ and the number of degrees of freedom $k_{1}=n-m-1=9$ равно $t_{\text {крит. }}(0,05 ; 9)=2,26$. Since the observed values of t-statistics for all coefficients are greater than the critical value of Student's criterion, it can be concluded that the coefficients of the regression equation are statistically significant and reliable.

Analyze the resulting equation of the multiple linear regression:

$$
y=116,913+0,367 x_{1}-0,051 x_{2}
$$

- with an increase in the output of pupils of 11 classes from general education schools by 10 thousand people, the number of universities increases by 4 units. Since the number of graduates has decreased in the last 
decade, it is better to draw the opposite conclusion: a decrease in graduates of general education schools by 10 thousand people entails a decrease in the number of universities by 4 units;

- the additional opening of 100 colleges leads to the closure of 5 universities.

Determine the average aggregate coefficients of elasticity:

$$
\begin{aligned}
& E_{y x_{1}}=b_{1} \cdot \frac{\overline{x_{1}}}{\bar{y}}=0,367 \cdot \frac{153,75}{142,17}=0,40 \%, \\
& E_{y x_{2}}=b_{2} \cdot \frac{\overline{x_{2}}}{\bar{y}}=-0,051 \cdot \frac{616,75}{142,17}=-0,22 \% .
\end{aligned}
$$

After analyzing these elasticities, we obtain the following conclusions:

1) when increasing the number of students in grades 11 from secondary schools $\left(x_{1}\right)$ at $1 \%$ of the average level, the number of universities $(y$ )increased by $0.40 \%$ of its average level with a constant number of colleges. Reverse: while reducing graduates of secondary schools $\left(x_{1}\right)$ at $1 \%$ of the average level, the number of universities $(y)$ reduced by $0.40 \%$ of its average level with a constant number of colleges;

2 ) with an increase in the number of colleges $\left(x_{2}\right)$ at $1 \%$ of the average level, the number of universities ( $y$ ) decreases by $0.22 \%$ of its average level with a constant number of graduates of secondary schools.

Now we will determine which of the two factors considered has the greatest influence on the change in the number of universities, for this we calculate the pairwise correlation coefficients using the Correlation analysis tool (Excel data analysis). The result is:

\begin{tabular}{rrrr}
\hline & $y$ & $x_{1}$ & $x_{2}$ \\
\hline$y$ & 1 & & \\
& 0,86 & & \\
$x_{1}$ & 691 & 1 & \\
& - & - & 1 \\
$x_{2}$ & 0,86261 & 0,73262 & \\
\hline
\end{tabular}

Thus, we can conclude that the number of universities is insignificant, but still it is more influenced by a factor graduation of 11 grades from general education schools, than a factor - the number of colleges.

In the future, the number of universities and educational programs participating in the accreditation process will increase, as a quality culture is gradually being formed in the country, which is the basis of the desire of universities to increase competitiveness. In addition, with the adoption of the Law of the Republic of Kazakhstan "On Amendments and Additions to Certain Legislative Acts on Education Issues No. 398-V of November 13, 2015", additional incentives for the development of accreditation were introduced. Firstly, this is an exemption from the procedure of state certification of programs that have passed institutional and program accreditation. In addition, from January 1, 2017, state-issued education certificates will be issued to students who have successfully mastered the educational programs of universities that have passed international accreditation with foreign or national accreditation bodies entered in the National Register. As a result, private universities also began to be active in the passage of accreditation to obtain the possibility of issuing a state diploma. However, from 2021, all universities, regardless of the form of ownership, will issue students with their own diplomas. Currently, the national quality assurance system for higher education consists of two parts: the procedures carried out by the Committee on the Control of Education and Science of the MES RK and the procedures carried out by independent non-governmental organizations. 


\section{ENTREPRENEURSHIP AND SUSTAINABILITY ISSUES}

ISSN 2345-0282 (online) http://jssidoi.org/jesi/

2019 Volume 6 Number 4 (June)

http://doi.org/10.9770/jesi.2019.6.4(66)

According to the analysis of the EUA, which we considered, the level of autonomy of higher education in Kazakhstan is far from ideal and is well below the average level of autonomy of 28 European countries. Kazakhstan is lagging behind the international trend in the replacement of centralized state control and regulation of management forms that emphasize the importance of policies, the establishment of national goals, decentralized institutional management and the use of financial policies. As the process of providing schools with greater autonomy develops, the government and national financial institutions should ensure that there are guarantees.

Since the ability to make cash management decisions is fundamental to any other management area, ensuring financial flexibility combined with accountability for results is an important first step in helping educational institutions become more efficient and innovative in their missions. As Kazakhstan moves forward in building a higher education system that takes into account the knowledge needs of a modern economy and society, it is necessary:

1) Strengthen governance at the institutional level to ensure deeper decentralization and greater financial, academic, and organizational flexibility, as well as the freedom to operate in higher education institutions:

- The government should support the development of the governing council system in the selection of managers within the public sector, ensure control of institutional operations, support and improve the efficiency of institutions and ensure the successful implementation of the mission of each educational institution.

2) To increase the transparency of management in public and private institutions of higher education:

- The government must adhere to an audit approach to ensure financial integrity. Conducting rigorous financial audits based on common standards should be a means of ensuring integrity and transparency;

- focus on intermediate and final results

- it is necessary to develop a national system of higher education data for analyzing the results of higher education and providing information to the process of developing national policies and funding strategies.

3) Within the academic community itself, develop and implement a reliable accreditation system and a national qualifications framework as the basis for ensuring and improving the quality of education, which will provide a rationale for the need for academic operational autonomy:

- to formulate a quality assurance process based on certification and inspections, as well as the use of accreditation, which will ensure the further development of high-quality education and research.

4) Clearly distinguish between the respective goals of the public and private sectors of the higher education system.

\section{Conclusions}

The review of technological solutions that allow to automate the functions of attraction and primary assessment of the applicant's suitability, make it possible to conclude:

- the market is in the stage of active saturation and search for new niches. Various promotion strategies are selected: deepening and / or expanding the functional of automated systems;

- strengthening of competitive positions of the companies that implement technological solutions is conducted including through representation of unique services, i.e. ones which have not been absent earlier in the market (for example, search of suitable applicants who are not in the status job search);

- solutions based on artificial intelligence technologies are becoming in demand, allowing to significantly expand the labor market supply, improve communication channels and interaction with the target audience.

At the same time, automation of the processes aimed at attracting and selecting candidates is accompanied by increased concerns of HR specialists regarding their replacement and reducing the importance of functional to ensure the current activities of the organization. 


\section{ENTREPRENEURSHIP AND SUSTAINABILITY ISSUES}

ISSN 2345-0282 (online) http://jssidoi.org/jesi/

2019 Volume 6 Number 4 (June)

http://doi.org/10.9770/jesi.2019.6.4(66)

\section{References}

Aimagambetov, Ye.B., Stefanov, D., Kuttybaeva, N. 2016. Assessing the level of competitiveness of the Republic of Kazakhstan on the basis of world rankings analysis. International Journal of Economic Perspectives, 10(3): 101-112

Ananeva, T. 2016. Why is the employee Brand Needed and How to Develop It in a Crisis. Personnel Service and Personnel Management of the Enterprise, 4 (9): 66-72.

Andonova, V., Nikolova, M. S., Dimitrov, D. 2019. Entrepreneurial Ecosystems in Unexpected Places https://doi.org/10.1007/978-3$\underline{319-98219-9}$

Boikova, A. L., Lapshina M. L. 2018. Automation of data processing procedures for the Personnel Department of a construction company. Current research directions of the XXI century: theory and practice, 5(41): 301-304.

Borisova, A. A. 2016. Organization of personnel management services (Russian practice). Novosibirsk: NSTU publishing house. 250p.

Butsyk, E.V., Demenenko, I.A. 2018. Recruitment in the era of digital HR, Vector of economy, 5(23): 28-34.

Cassella, A., Hanaki, N. 2016. Why personal ties cannot be thought. American Economic Review, 96(2): 261-264.

Chehabeddine, M., Tvaronavičienè, M. 2020. Securing regional development. Insights into Regional Development, 2(1), 430-442. http://doi.org/10.9770/IRD.2020.2.1(3)

Danshina, V. V., Vasilenko, I. O. 2016. Recruitment Technology "HR-POISK" as a form of implementation of innovative business development strategy. Business and Strategy, 2(3): 20-24.

Demenenko, I. A., Sarkisyan L. V. 2017. Staff recruitment and adaptation: innovative methods of HR management. NovaInfo.Ru, 2(60): 524-529.

Galazzi, M., Lang, K. 1998. Relative Wages, Wage Growth and Quit Behavior. Journal of Labor Economics, 2 (16): 3-6.

Glupenykaya, N. M. 2014. Research of personnel management systems of the organization. Prague: Vědeckovydavatelské centrum "Sociosféra-CZ". 96p.

Izbasarov, A. Zh. 2018. Automation of professional training management. Cloud of Science, 3(9): 27-31.

Khoreva, V., Vaiman V., Kostane E. 2018. Talent identification transparency: an alternative perspective. European Journal of International Management, 12(27): 35-39. https://doi.org/10.1504/EJIM.2019.096496

Lincényi, M., Č́rsky, J. 2020. Policy trusts in public policy in the Slovak Republic. Insights into Regional Development, 2(1), 456-468. http://doi.org/10.9770/IRD.2020.2.1(5)

Mansurov, R. E. 2018. HR-branding: how to improve the effectiveness of staff: training. St. Petersburg: BHV-Petersburg. 224p.

Nikishina, A. L. 2016. Research of modern technologies of stuffing. Modern scientific researches and innovations, 7(13): 24-28. http://web.snauka.ru/issues/2016/07/70081

Ozernikova, T. G. 2018. Personnel risks of Russian universities. Labor and social relations, 3(9): 81-92.

Tolymbekova, G.S., Sultanov, B.K., Taylak B.E. 2016. Automation of personnel management system of the enterprise. Innovative science, 4(5): 178-180. 


\section{ENTREPRENEURSHIP AND SUSTAINABILITY ISSUES}

ISSN 2345-0282 (online) http://jssidoi.org/jesi/

2019 Volume 6 Number 4 (June)

http://doi.org/10.9770/jesi.2019.6.4(66)

Uakhitzhanova, A., Shokhan, R., Omarova, A. et al. 2017. Entrepreneurial environment in the current financial politics of Kazakhstan. Journal of advanced research in law and economics. Romania. 8(4): 1361-1364.

Yershova, N. A., Sergeeva, N. N. 2017. Modern technologies of personnel management system in business structures. Moscow. MIRBIS. $312 p$.

\section{Acknowledgements}

This research was supported by the project, which has received funding from the Ministry of Education and Science of the Russian Federation, project 26.2024.2017/PCH. The results of the research were obtained within the framework of the state task of the project.

Alena BORISOVA is Doctor of Economic Sciences, Professor, Head of the Department of management of Novosibirsk State Technical University, Novosibirsk, Russia. Research interests: management, innovations, personnel management

ORCID ID: orcid.org/0000-0003-1501-2234

Madina RAKHIMBERDINOVA is PhD of the School of Business and Entrepreneurship of D. Serikbayev East Kazakhstan state technical university, Ust-Kamenogorsk, Kazakhstan. Research interests: management aspects of economic development, regional economy, marketing, innovation.

ORCID ID: orcid.org/0000-0001-9009-8686

Elvira MADIYAROVA is Candidate of Economic Sciences, Associate Professor, Dean of the School of Business and Entrepreneurship of D. Serikbayev East Kazakhstan state technical university, Ust-Kamenogorsk, Kazakhstan.

Research interests: financial aspects of economic development, regional economy, investments, financing, innovations.

ORCID ID: orcid.org/0000-0002-2944-6968

Inna RIASANTSEVA is Candidate of Economic Sciences, Associate Professor, Vice-rector for academic Affairs Novosibirsk state University of architecture, design and arts, Novosibirsk, Russia.

Research interests: management, business processes, personnel management

ORCID ID: orcid.org/0000-0003-2502-4722

Natalia MIKIDENKO is Candidate of Sociological Sciences, Associate Professor, Head of the Department Sociology, political science and psychology of Siberian state University of telecommunications and Informatics, Novosibirsk, Russia.

Research interests: education, business process management

ORCID ID: orcid.org/0000-0002-2232-8088

Register for an ORCID ID:

https://orcid.org/register

Copyright (C) 2020 by author(s) and VsI Entrepreneurship and Sustainability Center

This work is licensed under the Creative Commons Attribution International License (CC BY).

http://creativecommons.org/licenses/by/4.0/

(c) (i) Open Access 